\title{
Identification and Quantification of Plant Growth Regulators and Antioxidant Compounds in Aqueous Extracts of Padina durvillaei and Ulva lactuca
}

\author{
Israel Benítez García ${ }^{1}$, Ana Karen Dueñas Ledezma ${ }^{1}$, Emmanuel Martínez Montaño ${ }^{1,2}$, \\ Jesús Aarón Salazar Leyva ${ }^{1} \mathbb{D}$, Esther Carrera ${ }^{3}$ and Idalia Osuna Ruiz $1, * \mathbb{C}$ \\ 1 Maestría en Ciencias Aplicadas, Unidad Académica de Ingeniería en Biotecnología, Universidad Politécnica \\ de Sinaloa (UPSIN), Carretera Municipal Libre Mazatlán Higueras Km 3., Mazatlán, SIN 82199, Mexico; \\ ibenitez@upsin.edu.mx (I.B.G.); 2017031067@upsin.edu.mx (A.K.D.L.); emartinez@upsin.edu.mx (E.M.M.); \\ jsalazar@upsin.edu.mx (J.A.S.L.) \\ 2 Cátedras CONACYT, Consejo Nacional de Ciencia y Tecnología, Ciudad de México 03940, Mexico \\ 3 Instituto de Biología Molecular y Celular de Plantas (UPV-CSIC), Instituto de Biología Molecular y Celular \\ de Plantas (IBMCP), Universidad Politécnica de Valencia-Consejo Superior de Investigaciones \\ Científicas (CSIC), 46022 Valencia, Spain; ecarrera@ibmcp.upv.es \\ * Correspondence: iosuna@upsin.edu.mx
}

Received: 15 May 2020; Accepted: 15 June 2020; Published: 18 June 2020

\begin{abstract}
Aqueous seaweed extracts have diverse compounds such as Plant-Growth Regulators (PGRs) which have been utilized in agricultural practices for increasing crop productivity. Algal biomass of Padina durvillaei and Ulva lactuca have been suggested for use as biofertilizers because of plant growth-enhancing properties. This work aimed to identify the main PGRs and antioxidant properties in P. durvillaei and $U$. lactuca extracts, such as abscisic acid, auxins, cytokinins, gibberellins, jasmonates, and salicylates, to assess their potential use as biofertilizers that improve plant growth and crop yield. Phytochemical analyses of two seaweed extracts showed a significantly higher content of sulfates, flavonoids, and phenolic compounds in $P$. durvillaei extract, which could be linked to its higher antioxidant activity (DPPH, ABTS, and FRAP) compared to U. lactuca extract. The identification and quantification of PGRs showed two gibberellins (GA1 and GA4), abscisic acid (ABA), indoleacetic acid (IAA), three cytokinins (tZ, IP, and DHZ), jasmonic acid (JA), and salicylic acid (SA) in two seaweed extracts. However, GA4, $\mathrm{tZ}$, and DHZ contents were significantly higher in $P$. durvillaei compared to $U$. lactuca extracts. These findings evidence that $P$. durvillaei and $U$. lactuca extracts are suitable candidates for use as biofertilizers.
\end{abstract}

Keywords: seaweed extract; phytohormone profiling; fertilizers; antioxidant; plant growth regulators; brown seaweed; green algae

\section{Introduction}

Seaweed extracts have been used in agricultural activities due to their content of macroelements (alginate, agar, carrageenan, etc.), which activate the synthesis of endogenous hormones in plants $[1,2]$ and contribute microelements ( $\mathrm{N}, \mathrm{Ca}, \mathrm{Mg}, \mathrm{Mn}, \mathrm{B}, \mathrm{Br}, \mathrm{I}, \mathrm{Zn}, \mathrm{Cu}$, and $\mathrm{Co}$ ), amino acids, and vitamins that enrich soil in plant crops [3]. Besides, seaweed extracts contain biochemical compounds such as chlorophylls, carotenoids, and phenolics that confer antioxidant protection $[4,5]$. The antioxidant properties of algae extracts have been widely evaluated and attributed to sulfated polysaccharides, pigments, and phenolic compounds [4-8], which provide desirable characteristics for their potential use in crops, since, in addition to conferring antioxidant protection, compounds such as polysaccharides have been linked to growth promoting activities [8]. 
Some environmentally-friendly extraction methods generally include boiling or soaking with distilled water, which have been used as biostimulants for plant growth [9]. Phytohormone-like Plant-Growth Regulators (PGRs) have been identified in algal extracts, such as abscisic acid, auxins, cytokinins, gibberellins, jasmonates, or salicylates, all of which regulate plant cell metabolism and boost production and growth [10-12]. For this reason, marine algae have been used in agriculture as organic fertilizers to achieve sustainable crop production $[13,14]$ and counter the excessive use of fertilizers and synthetic hormones (e.g., 2.4-dichlorophenoxyacetic acid and naphthaleneacetic acid) that may potentially affect both the environment and humans [12,15].

Several authors have reported that algal extracts induce physiological processes in treated plants, such as germination, emergence, root growth, nutrient mobilization, maturation, tolerance to stress, and disease resistance; these responses are similar to those observed in plant crops treated with synthetic hormones [3,10,16-18]. Some seaweed extracts are marketed as liquid biofertilizers or biostimulants [3,16,19], mostly enriched with biomass of Ascophyllum nodosum, Sargassum spp., and Macrocystis pyrifera $[3,20,21]$. However, the different species of algae show variations regarding PGR biosynthesis [22]; thus, algal extracts exert variable physiological effects on different crops.

In Latin America, algal extracts have recently been used as biostimulants. Some reports demonstrate the benefits of the application of seaweed extracts harvested in coastal areas on various crops. The macroalgae M. pyrifera, Gelidium robustum, Chondracanthus canaliculatus, Sargassum spp., Ulva lactuca, and Padina gymnospora, have been used as biostimulants, fertilizers, and root promoters, as well as to stimulate growth and increase antifungal protection in tomato plants (Solanum lycopersicum) [20,23]. However, the exploitation of marine algae, mainly those involved in massive arrivals, is still incipient; moreover, it is not well known if improvements in yield and production of crops fertilized with algal extracts are due to the presence of PGRs in algal organic matter and/or if a possible contribution of other metabolites contribute to the biostimulant effects. Therefore, it is necessary to study the chemical and bioactive composition of a new algal extract when it is prepared to consider its potential use as plant grow stimulant.

In addition, PGRs in seaweeds have been insufficiently studied. Therefore, information is needed to support the use of marine sources, such as algae, to achieve sustainable agriculture practices in the future. This will reduce the environmental impact associated with the excessive use of chemical fertilizers, and also the potential risks to consumers resulting from the indiscriminate application of synthetic PGRs, along with the fact that algae provide other bioactive compounds that enhance protection against stress oxidative, improving plant health.

The objective of the present investigation was to characterize the chemical and bioactive composition (antioxidant activity, PGR identification and content) of aqueous extracts of the macroalgae Ulva lactuca and Padina durvillaei, and evaluate the use of such aqueous extracts as a potential biofertilizer.

\section{Material and Methods}

\subsection{Seaweed Collection and Reagents}

Specimens of the seaweeds Padina durvillaei (Bory Saint-Vicent, 1957) and Ulva lactuca (Linnaeus 1753) were collected in Mazatlan Bay, Sinaloa, Mexico ( $\left.23^{\circ} 1^{\prime} 29.1^{\prime \prime} \mathrm{LN}, 106^{\circ} 25^{\prime} 29.7^{\prime} \mathrm{LW}\right)$, in March 2017. Fresh samples were rinsed with distilled water, lyophilized, ground with a commercial grinder, and stored at $-20^{\circ} \mathrm{C}$ until used. All chemicals used in this research were analytical grade and supplied from Sigma (Sigma-Aldrich Co., St. Louis, MO, USA), unless otherwise specified.

\subsection{Seaweed Extracts}

Seaweed extracts were obtained using distilled water according to Tierney et al. [24], modified as follows: dried algal material was mixed with water at $21^{\circ} \mathrm{C}(1: 10, w: v)$ with stirring for $3 \mathrm{~h}$; then, the extract was filtered through a fiber glass filter $(1.2 \mu \mathrm{m}$ pore size $)$ and the algal residue extracted again 
(twice). Filtrates were pooled and centrifuged at $12,000 \times g$ and $4{ }^{\circ} \mathrm{C}$ for $20 \mathrm{~min}$; then, the supernatant was collected. Finally, the aqueous extract was lyophilized and stored at $-20^{\circ} \mathrm{C}$ until analyzed.

The extraction yield was calculated according to Equation (1):

$$
\text { Extraction yield }(\%)=(\text { grams of dry aqueous extract/grams of dry seaweed }) \times 100
$$

\subsection{Chemical Composition}

Carbohydrate content was measured using the phenol-sulfuric acid method [25] using D-glucose as standard. Soluble protein content was determined with Bradford's method using Bovine Serum Albumin (BSA) as standard [26].

Sulfate content was measured with the barium chloride-gelatin assay using potassium sulfate as standard [27]. The uronic acid content was determined with the sulfuric acid-carbazole colorimetric method using D-glucuronic acid as standard [28].

\subsubsection{Total Phenolic Content (TPC)}

Total soluble phenolic content was determined using the Folin-Ciocalteu method [29]. Dry samples were reconstituted with acetone $(1 \mathrm{mg} / \mathrm{mL})$; then, a $100 \mathrm{~mL}$ of each sample was mixed with $150 \mathrm{~mL}$ of Folin solution (previously diluted 1:1 with deionized water) followed by the addition of $1 \mathrm{~mL}$ of $2 \%$ sodium carbonate in $0.4 \%$ sodium hydroxide. The mixture was incubated in the dark at room temperature for $20 \mathrm{~min}$. The resulting blue complex was read in a spectrophotometer at $750 \mathrm{~nm}$. Phenolic content was expressed as mg of gallic acid equivalent (GAE) per g of sample (dry weight). A gallic acid standard curve was constructed at the concentration range of $0-0.25 \mathrm{mg} / \mathrm{mL}$.

\subsubsection{Total Flavonoids Content (TFC)}

Total flavonoid content was assessed according to Luximon-Ramma et al. [30]. Samples of solutions $(1 \mathrm{~mL})$ were diluted in equal volumes of a $2 \%$ aluminum chloride solution ( $2 \mathrm{~g}$ of $\mathrm{AlCl}_{3} \cdot 6 \mathrm{H}_{2} \mathrm{O}$ in $100 \mathrm{~mL}$ of methanol). The mixture was incubated at room temperature for $10 \mathrm{~min}$. Absorbance was read at $367 \mathrm{~nm}$. The results were expressed in $\mathrm{mg}$ of quercetin equivalents (QE) per gram of sample (dry weight). A quercetin standard curve was constructed at the concentration range of $0-0.5 \mathrm{mg} / \mathrm{mL}$.

\subsection{Antioxidant Evaluation}

\subsubsection{DPPH Free-Radical Scavenging Activity}

The free-radical scavenging potential of the seaweed extracts was analyzed according to the method proposed by Mensor et al. [31], modified as follows: a $100 \mathrm{~mL}$ aliquot of each extract (at concentrations of 0.0015 to $1.5 \mathrm{mg} / \mathrm{mL}$ ) was mixed with $900 \mathrm{~mL}$ of an ethanol solution of $0.3 \mathrm{mM}$ 2,2-diphenyl-1-picrylhydrazyl (DPPH); the mixture was incubated for $30 \mathrm{~min}$ in the dark at room temperature. Then, absorbance was measured at $518 \mathrm{~nm}$. Trolox was used as standard, whereas the DPPH solution served as control to calculate the degree of radical scavenging by samples as well as the reference standard.

The percentage of DPPH scavenging was calculated with Equation (2):

$$
\% \text { DPPH scavenging }=[(1-\text { Absorbance of sample }) / \text { Absorbance of Control }] \times 100
$$

\subsubsection{ABTS Free-Radical Scavenging Activity}

The scavenging activity of 2,2'-azinobis [3-ethylbenzthiazoline]-6-sulphonic acid (ABTS) was determined according to the method by Przygodzka et al. [32], modified as follows: the ABTS radical was previously activated for $12-16 \mathrm{~h}$ at room temperature in the dark; the resulting ABTS radical solution was diluted with ethanol and its absorbance read at $734 \mathrm{~nm}$, yielding a value of 0.80 . A $100 \mu \mathrm{L}$ aliquot of each sample (at a concentration of 0.0015 to $1.5 \mathrm{mg} / \mathrm{mL}$ ) was mixed with $2.9 \mathrm{~mL}$ of ABTS 
solution and the absorbance was read $10 \mathrm{~min}$ after mixing. Trolox was used as reference standard, whereas the ABTS radical solution served as control to calculate the degree of radical scavenging by samples as well as the reference standard.

The percentage of ABTS scavenging was calculated using Equation (3):

$$
\% \text { ABTS scavenging }=[(\mathrm{A}-\mathrm{B}) / \mathrm{A}] \times 100
$$

where $\mathrm{A}$ is absorbance of the ABTS control solution and B is absorbance of the test solution.

\subsubsection{Ferric Reducing Antioxidant Power (FRAP) Assay}

The FRAP assay was performed according to the methods of Benzie and Strain [33], with the minor modification reported by Szôllôsi and Varga [34]. The FRAP reagent was made from three different solutions: Solution A: $300 \mathrm{mM}$ acetate buffer, $\mathrm{pH}$ 3.6; Solution B: $10 \mathrm{mM}$ TPTZ dissolved in $40 \mathrm{mM} \mathrm{HCl}$; and Solution C: $20 \mathrm{mM} \mathrm{FeCl}_{3} \cdot 6 \mathrm{H}_{2} \mathrm{O}$. The work solution was prepared by mixing A, B, and $\mathrm{C}$ in a 10:1:1 ratio (by volume). For the assay, $100 \mu \mathrm{L}$ of sample were mixed with $1400 \mu \mathrm{L}$ of FRAP, and then incubated at room temperature for $30 \mathrm{~min}$ in the dark. Finally, absorbance was read at 593 $\mathrm{nm}$. Trolox was used as reference standard.

\subsection{Identification and Quantification of Plant Growth Regulator Profiles}

PGRs for acid hormones (gibberellins, GAs; indolacetic acid, IAA; jasmonic acid, JA; abscisic acid, ABA; and salicylic acid, SA), and cytokinins or basic hormones (dihydrozeatine, DHZ; isopentyladenine, $\mathrm{iP}$; and $\mathrm{t}$-zeatine, $\mathrm{tZ}$ ) were identified and quantified by ultra-high performance liquid chromatography-mass spectrometry (UHPLC-MS) using a Thermo Scientific ${ }^{\mathrm{TM}} \mathrm{Q}$ Exactive $^{\mathrm{TM}}$ Hybrid Quadrupole-Orbitrap mass spectrometer at Institute for Plant Molecular and Cell Biology (IBMCP), Spain. Extraction and separation of plant hormone profiles were performed as described by Seo et al. [35]. The lyophilized extract was suspended in $80 \%$ methanol (MeOH) containing $1 \%$ acetic acid, mixed by stirring for $1 \mathrm{~h}$ at $4{ }^{\circ} \mathrm{C}$ and centrifuged at $14000 \times g$ at $4{ }^{\circ} \mathrm{C}$ for $4 \mathrm{~min}$. The supernatant extract was stored at $-20^{\circ} \mathrm{C}$ overnight and then centrifuged at $14000 \times g$ at $4{ }^{\circ} \mathrm{C}$ for $4 \mathrm{~min}$. Then, the supernatant was dried in a vacuum evaporator. The dry residue was dissolved in $1 \%(v / v)$ acetic acid and passed consecutively through an Oasis HLB reverse-phase column (30 mg; Waters) and an Oasis MCX cation exchanger. Acid hormones were eluted with $\mathrm{MeOH}$ and basic hormones with $60 \%$ $\mathrm{MeOH}$ containing $5 \%$ aqueous ammonia [35]. The final residues were dried and dissolved in $5 \%(v / v)$ acetonitrile, $1 \%(v / v) \mathrm{MeOH}$, and $1 \%(v / v)$ acetic acid. Then, hormones were separated by UHPLC with a reverse Accucore C18 column (2.6 mm inner diameter, $100 \mathrm{~mm}$ length; Thermo Fisher Scientific) with a $2 \%$ to $55 \%(v / v)$ acetonitrile gradient containing $0.05 \%(v / v)$ acetic acid at $400 \mathrm{~mL}$ for $21 \mathrm{~min}$. The plant hormones were analyzed with a Q-Exactive mass spectrometer (Orbitrap detector; Thermo Fisher Scientific) by targeted selected ion monitoring (capillary temperature, $300^{\circ} \mathrm{C}$; S-lens RF level, 70; resolution, 70,000) and electrospray ionization (spray voltage, $3 \mathrm{kV}$; heater temperature, $150{ }^{\circ} \mathrm{C}$; sheath gas-flow rate, $1.90 \mathrm{~mL} / \mathrm{min}$; auxiliary gas-flow rate, $0.42 \mathrm{~mL} / \mathrm{min}$ ). The concentrations of plant hormones in extracts were determined using embedded calibration curves and the Xcalibur 2.2 SP1 build 48 and TraceFinder programs. The internal standards for quantification of each plant hormone were D6-ABA, D2-GA1, D2-GA4, D5-tZ, D3-DHZ, D6-iP, D2-IAA, D6-SA, and D2-JA (Olchemim Ltd., Olomouc, Czech).

\subsection{Statistical Analyses}

The results of all assays are reported as mean \pm standard deviation. Comparisons between groups were performed using the Student's $t$-test. Statistical significance was set at $p<0.05$.

All statistical analyses were performed using the statistical program Sigma Plot version 11.0 (2018 Systat Software, Inc.; Erkrath, Germany). 


\section{Results}

\subsection{Chemical Composition and Antioxidant Capacity Evaluation of Seaweed Extracts}

The highest extraction yield was achieved in the Ulva lactuca extract (Table 1), which was nearly twice the yield for Padina durvillaei $(7.55 \pm 4.05 \%$ and $3.34 \pm 1.20 \%$, respectively). With regard to the chemical composition of the soluble components in both extracts, similar contents of carbohydrates and uronic acids were found; however, the percentage of sulfates and the content of polyphenols and flavonoids varied, with higher values in the $P$. durvillaei extract $(6.63 \pm 0.7 \%, 34.26 \pm 1.39 \mathrm{GAE} / \mathrm{g}$, and $16.16 \pm 2.87 \mathrm{QE} / \mathrm{g}$, respectively). Soluble protein was found in the P. durvillaei extract (1.28 $\pm 0.5 \%)$, but not in the U. lactuca extract.

Table 1. Chemical composition of seaweed extracts.

\begin{tabular}{lll}
\hline & Padina Durvillaei & Ulva Lactuca \\
\hline Extraction Yield (\%) & $3.34 \pm 1.20$ & $7.55 \pm 4.05$ \\
\hline Chemical Composition (dwt.) & \\
\hline Soluble Protein (\%) & $1.28 \pm 0.56$ & N. D. \\
Carbohydrates (\%) & $16.36 \pm 0.08$ & $16.19 \pm 0.07$ \\
Uronic Acids (\%) & $8.79 \pm 0.60$ & $8.01 \pm 0.21$ \\
Sulfates (\%) & $6.63 \pm 0.76 \mathrm{a}$ & $4.05 \pm 1.13 \mathrm{~b}$ \\
Total Polyphenols Content (mg GAE/g) & $34.26 \pm 1.39 \mathrm{a}$ & $27.29 \pm 1.57 \mathrm{~b}$ \\
Total Flavonoids Content (mg QE/g) & $16.16 \pm 2.87 \mathrm{a}$ & $10.22 \pm 0.96 \mathrm{~b}$ \\
\hline
\end{tabular}

All chemicals components are expressed on dry weight basis (dwt.). Values represented are mean of triplicates; values followed by different letters are significantly different at $p<0.05$. N.D., not detected; GAE $/ \mathrm{g}$, $\mathrm{mg}$ of Gallic acid equivalent per gram of seaweed extract; $\mathrm{QE} / \mathrm{g}, \mathrm{mg}$ of Quercetin equivalent per gram of seaweed extract.

Regards to the antioxidant activity in extracts (Figure 1), greater activity was recorded in the $P$. durvillaei extract for the DPPH and ABTS tests, with 0.37 and 0.07 TEAC per gram of extract, respectively (Figure 1A,B). The antioxidant capacity, as measured by DPPH, was three-fold for the P. durvillaei extract versus the $U$. lactuca extract $(0.13 \mathrm{TEAC} / \mathrm{g})$. The ferric reducing antioxidant power (FRAP) was only recorded in $P$. durvillaei extracts, with TEAC values of $0.02 / \mathrm{g}$ (Figure 1C).

\subsection{PGR Contents in Seaweed Extracts}

Two groups of PGRs (acidic and basic) were identified by UHPLC-MS (Figure 2); their identification and quantification in aqueous algal extracts correspond to abcisic acid (ABA), an auxin (IAA), three cytokinins (dihydrozeatine, DHZ; isopentyladenine, IP; and t-zeatine, tZ), two gibberellins (GA1 and GA4), jasmonic acid (JA), and salicylic acid (SA). The quantification of acidic PGRs showed that SA and IAA are the main chemical groups in both algal extracts. SA concentration was $88.8 \pm 52.9 \mathrm{ng} / \mathrm{g}$ in the P. durvillaei extract and $67.6 \pm 4.2 \mathrm{ng} / \mathrm{g}$ in the $U$. lactuca extract (Figure 2A). IAA concentration was slightly higher in U. lactuca $(49.3 \pm 5.2 \mathrm{ng} / \mathrm{g})$ relative to $P$. durvillaei $(39.0 \pm 12.8 \mathrm{ng} / \mathrm{g})$, but these differences were not statistically significant (Figure 2A). On the other hand, the U. lactuca extract contained the highest ABA concentration $(17.8 \pm 5.2 \mathrm{ng} / \mathrm{g})$ compared to the $P$. durvillaei extract $(1.5$ $\pm 0.5 \mathrm{ng} / \mathrm{g}$ ); JA concentrations were similar in both extracts (Figure 2A). With regard to gibberellins, the highest GA4 concentration $(1.51 \pm 0.64 \mathrm{ng} / \mathrm{g})$ was noted in the $U$. lactuca extract, compared to the $P$. durvillaei extract $(0.37 \pm 0.08 \mathrm{ng} / \mathrm{g})$, while GA1 showed similar levels in both extracts (Figure 2B). 


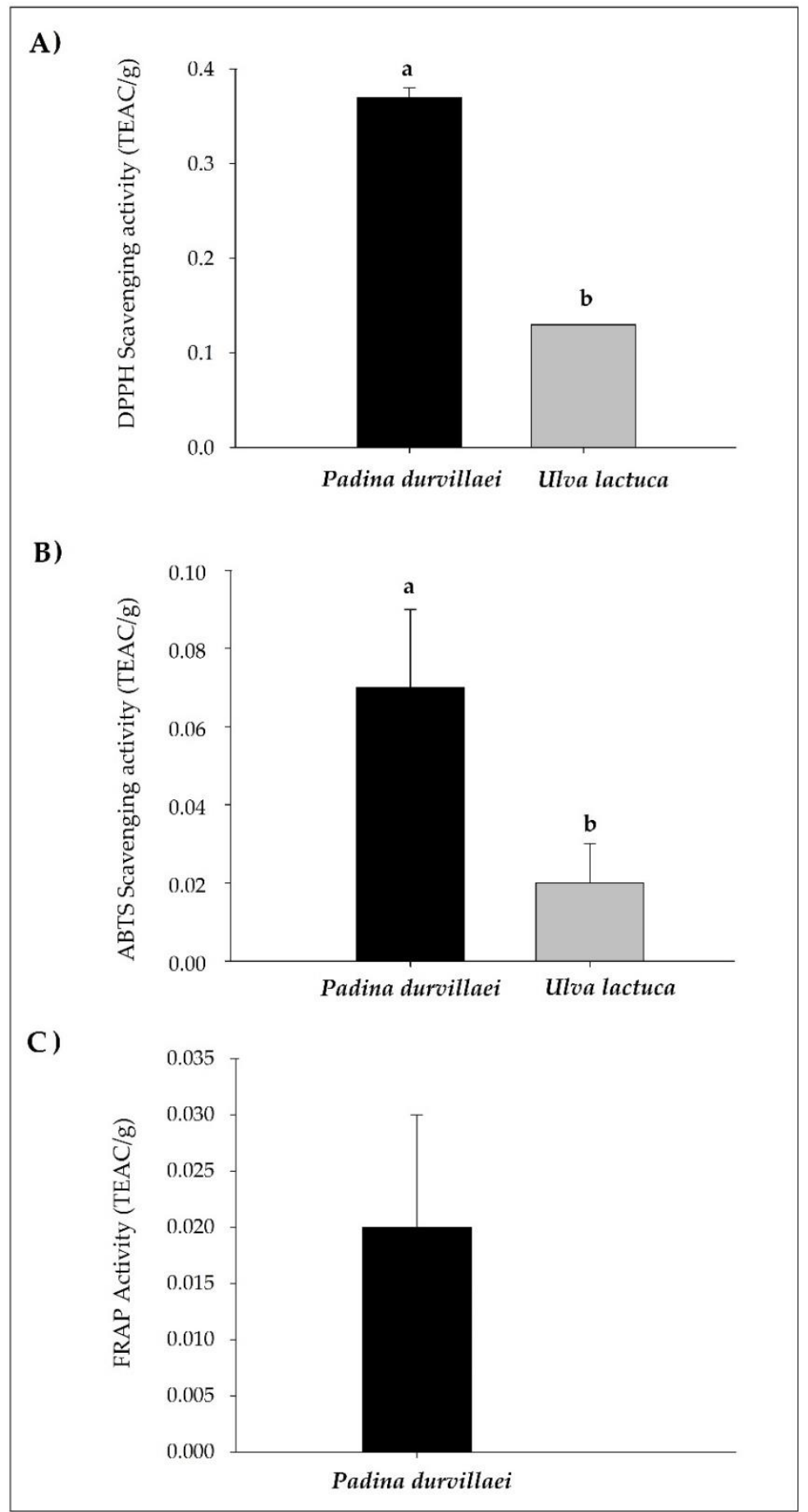

Figure 1. In vitro antioxidant activity of seaweed extracts of Padina durvillaei and Ulva lactuca assessed by different methods: (A) DPPH scavenging activity; (B) ABTS scavenging activity; and (C) FRAP activity. Bars represent mean of triplicates $\pm \mathrm{SD}$; different letters are significantly different at $p<0.05$. TEAC $/ \mathrm{g}$, mmol of Trolox equivalent of antioxidant activity per gram of seaweed extract.

The quantification of basic PGRs (Figure 2C) showed that $\mathrm{tZ}$ is the most abundant hormone in the U. lactuca extract $(10.95 \pm 4.31 \mathrm{ng} / \mathrm{g})$. On the other hand, IP concentrations were similar in both extracts (4.41 $1.85 \mathrm{ng} / \mathrm{g}$ in P. durvillaei and $4.57 \pm 0.38 \mathrm{ng} / \mathrm{g}$ in $U$. lactuca). DHZ concentrations were low in both extracts, with $1.09 \pm 0.44 \mathrm{ng} / \mathrm{g}$ in $P$. durvillaei and $0.77 \pm 0.09 \mathrm{ng} / \mathrm{g}$ in $U$. lactuca. 


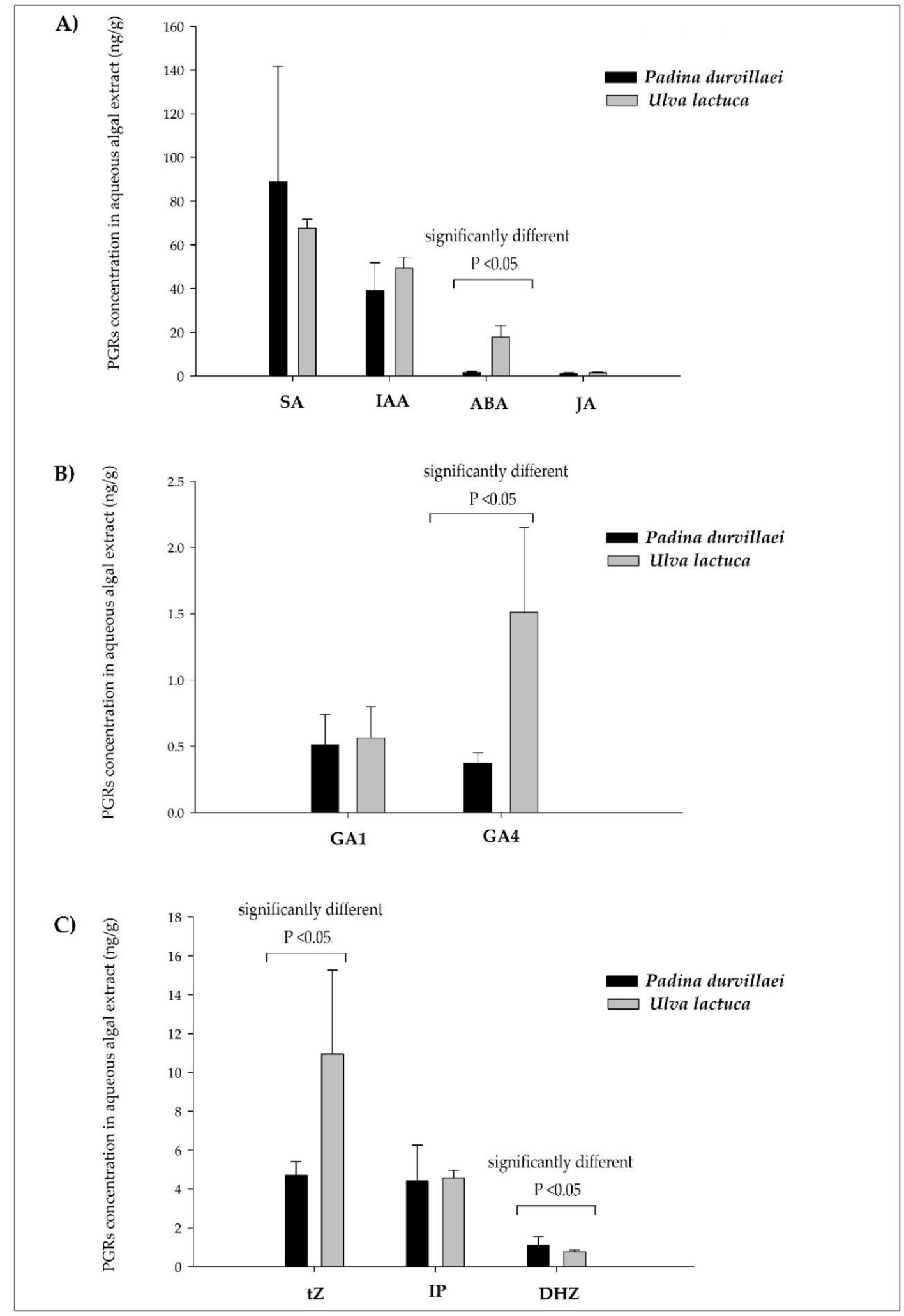

Figure 2. PGRs quantification by UHPLC-MS in aqueous algal extracts of Padina durvillaei and Ulva lactuca: (A) acid PGRs (salicylic acid, SA; indolacetic acid, IAA; abscisic acid, ABA; and jasmonic acid, JA); (B) gibberellins (GA1 and GA4); and (C) cytokinins or basic hormones (t-zeatine, tZ; isopentyladenine, iP; and dihydrozeatine, $\mathrm{DHZ}$ ). Bars represent mean of triplicates $\pm \mathrm{SD}$. Significant differences at $p<0.05$ of some type of PGR between algal extracts have been indicated. 


\section{Discussion}

In this study, we used two species of algae to obtain aqueous extracts. Both species are frequently observed as floating seaweed mats that reach the northeast Pacific coasts; they belong to different taxonomic groups: P. durvillaei to the class Phaeophyceae (brown algae) and U. lactuca to the class Chlorophyceae (green algae). This leads to potential chemo-taxonomic differences, coupled with spatiotemporal variations associated with growth and environmental adaptation. Ultimately, these differences result in the variability in chemical composition, as observed in the aqueous extracts analyzed in the present study. Such variability has also been observed in other studies reporting taxonomic compositional differences in marine algae thriving in temperate waters (e.g., Caulerpa sertularioides, Rhizoclonium riparium, Gracilaria vermoculophylla, and Spyridia filamentosa), including the presence of biochemical compounds associated with bioactive characteristics, such as fucosterol, $\beta$-sitosterol, omega- 3 fatty acids, and various photosynthetic pigments [36]. An example is the case of temperate macroalgae in Denmark, where aqueous extracts were analyzed from 16 species of macroalgae in different taxonomic families and whose total polyphenolics content showed no statistically significant differences [6].

From the compositional differences observed in macroalgae, their extracts exhibit different levels of biological activity, particularly antioxidant activity; the present study recorded a higher activity of the P. durvillaei extract. This extract has a higher content of polyphenols and flavonoids, compounds with a known ability to scavenge synthetic radicals in in vitro tests (DPPH and ABTS), as well as the presence of sulfated polysaccharides. Note that no ferric reducing antioxidant power (FRAP) was detected in Ulva extracts, while it was very weak in the Padina extract; this may indicate the influence of compositional characteristics of sulfated polysaccharides in extracts. Besides, substances that interfere in the antioxidant tests used were found, such as proteins and uronic acids. High contents of sulfates, protein, and uronic acids were also observed, which have been associated with the low antioxidant activity observed in polysaccharide fractions isolated from aqueous extracts of green algae such as Ulva fasciata [37].

It was also observed that the presence of fucose in sulfated polysaccharides from brown algae conferred a higher ferric reducing activity relative to polysaccharides from green algae that do not contain this sugar (e.g., Sargassum wightii vs. Ulva lactuca) [7]; a similar effect is likely to influence the behavior observed in our study. In general, secondary metabolites such as polyphenols are more abundant in brown algae, with some, e.g., 2,4,6-trihydroxybenzoate (a benzoic acid derivative), being unique to this group of macroalgae [38]. It should be stressed that polyphenols are compounds with electrons that can be donated, thus conferring a higher antioxidant response when classified methods are used, including electron transfer such as ABTS and FRAP [39].

On the other hand, a higher antioxidant activity was observed in both extracts with the DPPH method. This indicates that the antioxidant chemicals in extracts function mainly through a reaction mechanism involving the transfer of a hydrogen atom from these compounds [6]; this sort of antioxidant capacity was about three times higher for the P. durvillaei extract relative to the U. lactuca extract. Some studies have shown that aqueous extracts from brown algae have a higher polyphenolics content relative to red and green algae, which confer on them greater antioxidant activity. For example, the antioxidant activity (assessed with the DPPH test) of aqueous extracts from the brown algae Fucus serratus and F. vesiculus was 42 times higher than in extracts from the green algae Enteromorpha intestinalis and 89 times higher than in Ulva lactuca [6]. The same behavior was observed for the FRAP test, since the reducing power from brown algae extracts was 3-5 times lower relative to green algae; total polyphenols content and type of polyphenols (ferulic, vanillic, coumaric, and gallic acids) contribute highly to the antioxidant and reducing activities [6]. Likewise, Wang et al. [8] reported higher total polyphenols contents in aqueous extracts of brown algae relative to red and green algae, which led to a high in vitro antioxidant activity measured with DPPH for extracts obtained from Fucus vesiculus, F. serratus, Ascophyllum nodosum, and Laminaria hyperborea, with antioxidant values representing up to 200 times the antioxidant activity observed for Ulva lactuca. 
Originally, PGRs in plants have been found in trace amounts (fmol to pmol per gram, wet weight), with gibberellins, abscisic acid, cytokinins, indoleacetic acid, ethylene, jasmonates, and salicylates as those most studied PGRs [40]. Unlike plants, algae accumulate higher concentrations of PGRs (pmol to $\mu$ mol per gram fresh weight), mainly auxins and cytokinins; some authors hypothesize that bioactive gibberellins inducing germination and growth may also accumulate, as well as jasmonates and salicylates. However, few species of macroalgae contain gibberellins, jasmonate, and salicylates [3].

The presence and number of PGRs in algae and terrestrial plants differ according to the species or variety [12,22]. For example, Mori et al. [41] reported the identification of auxins, cytokinins, and salicylic acid (SA), but not AG3 and jasmonates, in extracts of two red algae (Pyropia yezoensis and Bangia fuscopurpurea). Another study involving fourteen seaweeds in the Turkey coast reported the presence of five PGRs (t-zeatine (t-Z), IAA, GA3, ABA, and 6-benzyl amino purine (BAP) in two algae, namely Petalonia fascia (brown algae) and Caulerpa racemosa var. cylindracea (green algae), and the absence of GA3 and ABA in the eleven remaining seaweeds, including Sargassum vulgare and Ulva rigida, which are used to produce biofertilizers [22]. By contrast, this work identified nine PGRs (SA, IAA, ABA, JA, t-Z, IP, DHZ, GA4, and GA1) in extracts from two algae (P. durvillaei and U. lactuca) distributed along the Mexican Pacific coasts. The presence of SA and JA is worth noting, as these have not been identified in any other algae; these PGRs strengthen the defense capabilities of plants by inducing acquired systemic resistance (SAR).Gibberellins GA4 and GA1 are also present, which show biological activity in plants.

Mexico produces and markets fertilizers based on extracts of seaweeds such as Macrocystis pyrifera, Sargassum spp, Ascophyllum nodosum, Laminaria spp, Egregia menziesii, and Gelidium robustum, using methods that involve hydrothermal treatment under acidic, neutral, and alkaline conditions [20]. These extracts boost germination, rooting, and plant growth, likely resulting from the content of polysaccharides, macro- and microelements [20,42-44]. However, although studies on algal extracts show evident effects on plant growth, few reports demonstrate the presence of PGRs in such extracts, and these can only be inferred from the physiological effects shown [42]. Unlike marketed products based on seaweed extracts containing polysaccharides obtained using methods under alkaline, acidic, and neutral conditions, this study used aqueous extraction, which ensured the extraction of nine PGRs in high concentrations for use in plant crops.

Studies related to the identification and quantification of PGRs in algae, such as Ascophyllum nodosum and Sargassum muticum (Phaeophyceae) used in the development of biofertilizers [45], report results differing from those obtained in this work. For example, A. nodosum, whose extracts are used in products such as Phylgreen ${ }^{\circledR}$, contains concentrations of IAA, ABA, and IP of 7.53, 17.63, and $16.11 \mathrm{pmol} / \mathrm{g}$ dry weight (DW), respectively [46], while extracts of Sargassum heterophyllum accumulate IP and $\mathrm{t}-\mathrm{Z}$ at 48.2 and $2.4 \mathrm{pmol} / \mathrm{g}$ DW, respectively [47]. In contrast, this study reports concentrations in extracts of $P$. durvillaei (IAA $39.0 \mathrm{ng} / \mathrm{g}$, ABA $1.5 \mathrm{ng} / \mathrm{g}$, IP $4.41 \mathrm{ng} / \mathrm{g}$ DW, and t-Z $4.7 \mathrm{ng} / \mathrm{g}$ DW) and U. lactuca (IAA $49.3 \mathrm{ng} / \mathrm{g}$, ABA $17.8 \mathrm{ng} / \mathrm{g}$, IP $4.57 \mathrm{ng} / \mathrm{g}$, and t-Z $10.95 \mathrm{ng} / \mathrm{g}$ DW) that are higher than those reported by Jannin et al. [46] and Stirk et al. [47]. This finding suggests that the algae studied here are potential alternatives suitable for use as biofertilizers based on their high PGR content.

On the other hand, the identification of GA1 and GA4 in this study contrasts with reports by Dumale et al. (2018) [48], who identified GA3 in extracts of Caulerpa racemosa (green algae), and by Shoubaky et al. [49] in U. lactuca extracts, who identified two groups of PGRs, namely ABA and eight gibberellins (GA7 methyl ester, GA8, GA13, GA19, GA23, GA44, and GA75). However, the gibberellins identified in extracts of $P$. durvillaei and $U$. lactuca are considered to be biologically active in plants, contrary to those reported by Shoubaky et al. [49]; this difference is relevant, as PGRs should be in the active form for use in plant crops [50] Note that the identification of PGRs in P. durvillaei extracts has not been reported in the literature previously; thus, the data in this paper support the potential use of brown algae or extracts thereof as growth promoters in plants of agricultural importance. 


\section{Conclusions}

The present study focused on the analysis of the main PGRs and the biochemical characterization of their aqueous extracts in two macroalgae involved in massive arrivals. The chromatographic analysis revealed the presence of abcisic acid (AB), auxins (IAA), cytokinins (tZ, IP, and DHZ), gibberellins (AG1 and AG4), jasmonates (AJ), and salicylates (AS); of these, AS attained the highest levels in both extracts. On the other hand, the phytochemical analysis revealed the presence of soluble compounds such as carbohydrates and uronic acids, as well as bioactive compounds such as polyphenols and flavonoids that confer antioxidant activity to extracts. The identification of PGRs in algal extracts opens the possibilities for use of algae involved in massive arrivals as potential environmentally-friendly organic biofertilizers that serve as growth promoters in agricultural crops.

Author Contributions: Conceptualization, I.B.G. and I.O.R.; methodology, A.K.D.L., E.C., I.O.R., and I.B.G.; validation, J.A.S.L., E.C., I.B.G., and I.O.R.; formal analysis, E.M.M., E.C., and I.O.R.; investigation, A.K.D.L., I.B.G., and I.O.R.; resources, E.C., I.O.R., and I.B.G.; data curation, I.B.G. and I.O.R.; writing-original draft preparation, I.B.G. and I.O.R.; writing-review and editing, I.B.G., E.C., I.O.R., E.M.M., and J.A.S.L.; visualization, E.M.M. and J.A.S.L.; supervision, I.O.R., I.B.G., E.M.M., and J.A.S.L.; project administration, I.B.G. and I.O.R.; and funding acquisition, I.O.R. and I.B.G. All authors have read and agreed to the published version of the manuscript.

Funding: This research received no external funding.

Acknowledgments: The authors are grateful to the Universidad Politécnica de Sinaloa and the Instituto de Biología Molecular y Celular de Plantas (IBMCP) CSIC-Universidad Politécnica de Valencia for providing the necessary facilities to carry out the research.

Conflicts of Interest: The authors declare no conflict of interest.

\section{References}

1. Ben Salah, I.; Aghrouss, S.; Douira, A.; Aissam, S.; El Alaoui-Talibi, Z.; Filali-Maltouf, A.; El Modafar, C. Seaweed polysaccharides as bio-elicitors of natural defenses in olive trees against verticillium wilt of olive. J. Plant Interact. 2018, 13, 248-255. [CrossRef]

2. Vera, J.; Castro, J.; Gonzalez, A.; Moenne, A. Seaweed Polysaccharides and Derived Oligosaccharides Stimulate Defense Responses and Protection Against Pathogens in Plants. Mar. Drugs 2011, 9, 2514-2525. [CrossRef]

3. Khan, W.; Rayirath, U.P.; Subramanian, S.; Jithesh, M.N.; Rayorath, P.; Hodges, D.M.; Critchley, A.T.; Craigie, J.S.; Norrie, J.; Prithiviraj, B. Seaweed Extracts as Biostimulants of Plant Growth and Development. J. Plant Growth Regul. 2009, 28, 386-399. [CrossRef]

4. Osuna-Ruiz, I.; López-Saiz, C.-M.; Burgos-Hernández, A.; Velázquez, C.; Nieves-Soto, M.; Hurtado-Oliva, M.A. Antioxidant, antimutagenic and antiproliferative activities in selected seaweed species from Sinaloa, Mexico. Pharm. Biol. 2016, 54, 2196-2210. [CrossRef] [PubMed]

5. Osuna-Ruíz, I.; Salazar-Leyva, J.A.; López-Saiz, C.M.; Burgos-Hernández, A.; Hernández-Garibay, E.; Lizardi-Mendoza, J.; Hurtado-Oliva, M.A. Enhancing antioxidant and antimutagenic activity of the green seaweed Rhizoclonium riparium by bioassay-guided solvent partitioning. J. Appl. Phycol. 2019, 31, 3871-3881. [CrossRef]

6. Farvin, K.S.; Jacobsen, C. Phenolic compounds and antioxidant activities of selected species of seaweeds from Danish coast. Food Chem. 2013, 138, 1670-1681. [CrossRef] [PubMed]

7. Meenakshi, S.; Umayaparvathi, S.; Arumugam, M.; Balasubramanian, T. In vitro antioxidant properties and FTIR analysis of two seaweeds of Gulf of Mannar. Asian Pac. J. Trop. Biomed. 2011, 1, 66-70. [CrossRef]

8. Wang, T.; Jónsdóttir, R.; Olafsdottir, G. Total phenolic compounds, radical scavenging and metal chelation of extracts from Icelandic seaweeds. Food Chem. 2009, 116, 240-248. [CrossRef]

9. Godlewska, K.; Michalak, I.; Tuhy, Ł.; Chojnacka, K. Plant Growth Biostimulants Based on Different Methods of Seaweed Extraction with Water. BioMed Res. Int. 2016, 2016, 1-11. [CrossRef]

10. Ghaderiardakani, F.; Collas, E.; Damiano, D.K.; Tagg, K.; Graham, N.S.; Coates, J.C. Effects of green seaweed extract on Arabidopsis early development suggest roles for hormone signalling in plant responses to algal fertilisers. Sci. Rep. 2019, 9, 1983. [CrossRef] 
11. Prasad, K.; Das, A.K.; Oza, M.D.; Brahmbhatt, H.; Siddhanta, A.K.; Meena, R.; Eswaran, K.; Rajyaguru, M.R.; Ghosh, P.K. Detection and Quantification of Some Plant Growth Regulators in a Seaweed-Based Foliar Spray Employing a Mass Spectrometric Technique sans Chromatographic Separation. J. Agric. Food Chem. 2010, 58, 4594-4601. [CrossRef] [PubMed]

12. Yalçın, S.; Şükran Okudan, E.; Karakaş, Ö.; Önem, A.N.; Sözgen Başkan, K. Identification and quantification of some phytohormones in seaweeds using UPLC-MS/MS. J. Liq. Chromatogr. Relat. Technol. 2019, 42, 475-484. [CrossRef]

13. Hurtado, A.Q.; Neish, I.C.; Critchley, A.T. Phyconomy: The extensive cultivation of seaweeds, their sustainability and economic value, with particular reference to important lessons to be learned and transferred from the practice of eucheumatoid farming. Phycologia 2019, 58, 472-483. [CrossRef]

14. Kumar, R.; Trivedi, K.; Anand, K.G.V.; Ghosh, A. Science behind biostimulant action of seaweed extract on growth and crop yield: Insights into transcriptional changes in roots of maize treated with Kappaphycus alvarezii seaweed extract under soil moisture stressed conditions. J. Appl. Phycol. 2019, 32, 599-613. [CrossRef]

15. Haç-Wydro, K.; Flasiński, M. The studies on the toxicity mechanism of environmentally hazardous natural (IAA) and synthetic (NAA) auxin-The experiments on model Arabidopsis thaliana and rat liver plasma membranes. Colloids Surf. B Biointerfaces 2015, 130, 53-60. [CrossRef]

16. Arioli, T.; Mattner, S.W.; Winberg, P. Applications of seaweed extracts in Australian agriculture: Past, present and future. J. Appl. Phycol. 2015, 27, 2007-2015. [CrossRef]

17. Hayashi, L.; Reis, R.P.; Dos Santos, A.A.; Castelar, B.; Robledo, D.; De Vega, G.B.; Msuya, F.E.; Eswaran, K.; Yasir, S.M.; Ali, M.K.M.; et al. The cultivation of Kappaphycus and Eucheuma in tropical and sub-tropical waters. In Tropical Seaweed Farming Trends, Problems and Opportunities; Springer: Cham, Switzerland, 2017; pp. 55-90.

18. Stirk, W.A.; Van Staden, J. Plant growth regulators in seaweeds: Occurrence, regulation and functions. In Advances in Botanical Research; Elsevier: Amsterdam, The Netherlands, 2014; Volume 71, pp. 125-159.

19. Uthirapandi, V.; Suriya, S.; Boomibalagan, P.; Eswaran, S.; Ramya, S.S.; Vijayanand, N.; Kathiresan, D. Bio-Fertilizer potential of seaweed liquid extracts of marine macro algae on growth and biochemical parameters of Ocimum sanctum. J. Pharm. Phytochem. 2018, 7, 3528-3532.

20. Hernández-Herrera, R.M.; Santacruz-Ruvalcaba, F.; Briceño-Domínguez, D.R.; Di Filippo-Herrera, D.A.; Hernández-Carmona, G. Seaweed as potential plant growth stimulants for agriculture in Mexico. Hidrobiológica 2018, 28, 129-140. [CrossRef]

21. Sharma, H.S.; Fleming, C.; Selby, C.; Rao, J.R.; Martin, T. Plant biostimulants: A review on the processing of macroalgae and use of extracts for crop management to reduce abiotic and biotic stresses. J. Appl. Phycol. 2013, 26, 465-490. [CrossRef]

22. Yalçın, S.; Okudan, E.Ş.; Karakaş, Ö.; Önem, A.N. Determination of Major Phytohormones in Fourteen Different Seaweeds Utilizing SPE-LC-MS/MS. J. Chromatogr. Sci. 2019, 58, 98-108. [CrossRef]

23. Hernández-Herrera, R.M.; Santacruz-Ruvalcaba, F.; Ruiz-López, M.A.; Norrie, J.; Hernández-Carmona, G. Effect of liquid seaweed extracts on growth of tomato seedlings (Solanum lycopersicum L.). J. Appl. Phycol. 2013, 26, 619-628. [CrossRef]

24. Tierney, M.S.; Smyth, T.; Rai, D.K.; Soler-Vila, A.; Croft, A.K.; Brunton, N. Enrichment of polyphenol contents and antioxidant activities of Irish brown macroalgae using food-friendly techniques based on polarity and molecular size. Food Chem. 2013, 139, 753-761. [CrossRef] [PubMed]

25. Dubois, M.; Gilles, K.A.; Hamilton, J.K.; Rebers, P.A.; Smith, F. Colorimetric Method for Determination of Sugars and Related Substances. Anal. Chem. 1956, 28, 350-356. [CrossRef]

26. Bradford, M.M. A rapid and sensitive method for the quantitation of microgram quantities of protein utilizing the principle of protein-dye binding. Anal. Biochem. 1976, 72, 248-254. [CrossRef]

27. Dodgson, K.; Price, R.; Lash, J.W.; Whitehouse, M.W.; Moretti, A.; Harborne, J. A note on the determination of the ester sulphate content of sulphated polysaccharides. Biochem. J. 1962, 84, 106-110. [CrossRef] [PubMed]

28. Bitter, T.; Muir, H. A modified uronic acid carbazole reaction. Anal. Biochem. 1962, 4, 330-334. [CrossRef]

29. Marigo, G. Sur une méthode de fractionnement et d'estimation des composés phénoliques chez les végétaux. Annalusis 1973, 2, 106-110. 
30. Luximon-Ramma, A.; Bahorun, T.; Soobrattee, M.A.; Aruoma, O.I. Antioxidant Activities of Phenolic, Proanthocyanidin, and Flavonoid Components in Extracts of Cassia fistula. J. Agric. Food Chem. 2002, 50, 5042-5047. [CrossRef]

31. Mensor, L.L.; Menezes, F.S.; Leitão, G.G.; Reis, A.S.; Dos Santos, T.C.; Coube, C.S.; Leitão, S.G. Screening of Brazilian plant extracts for antioxidant activity by the use of DPPH free radical method. Phytother. Res. 2001, 15, 127-130. [CrossRef]

32. Przygodzka, M.; Zielińska, D.; Ciesarová, Z.; Kukurová, K.; Zieliński, H. Comparison of methods for evaluation of the antioxidant capacity and phenolic compounds in common spices. LWT-Food Sci. Technol. 2014, 58, 321-326. [CrossRef]

33. Benzie, I.; Strain, J. The Ferric Reducing Ability of Plasma (FRAP) as a Measure of "Antioxidant Power": The FRAP Assay. Anal. Biochem. 1996, 239, 70-76. [CrossRef] [PubMed]

34. Szőllősi, R.; Varga, I.S.I. Total antioxidant power in some species of Labiatae: Adaptation of FRAP method. Acta Biol. Szeged. 2002, 46, 125-127.

35. Seo, M.; Jikumaru, Y.; Kamiya, Y. Profiling of hormones and related metabolites in seed dormancy and germination studies. In Seed Dormancy; Springer: Boston, MA, USA, 2011; pp. 99-111.

36. Osuna-Ruiz, I.; Nieves-Soto, M.; Manzano-Sarabia, M.M.; Hernández-Garibay, E.; Lizardi-Mendoza, J.; Burgos-Hernández, A.; Hurtado-Oliva, M.Á. Gross chemical composition, fatty acids, sterols, and pigments in tropical seaweed species off Sinaloa, Mexico. Cienc. Mar. 2019, 45, 101-120. [CrossRef]

37. Shao, P.; Chen, M.; Pei, Y.; Sun, P. In intro antioxidant activities of different sulfated polysaccharides from chlorophytan seaweeds Ulva fasciata. Int. J. Biol. Macromol. 2013, 59, 295-300. [CrossRef] [PubMed]

38. Belghit, I.; Rasinger, J.D.; Heesch, S.; Biancarosa, I.; Liland, N.S.; Torstensen, B.; Waagbø, R.; Lock, E.J.; Bruckner, C.G. In-depth metabolic profiling of marine macroalgae confirms strong biochemical differences between brown, red and green algae. Algal Res. 2017, 26, 240-249. [CrossRef]

39. Prior, R.L.; Wu, X.; Schaich, K. Standardized Methods for the Determination of Antioxidant Capacity and Phenolics in Foods and Dietary Supplements. J. Agric. Food Chem. 2005, 53, 4290-4302. [CrossRef]

40. Šimura, J.; Antoniadi, I.; Široká, J.; Tarkowská, D.; Strnad, M.; Ljung, K.; Novak, O. Plant Hormonomics: Multiple Phytohormone Profiling by Targeted Metabolomics. Plant Physiol. 2018, 177, 476-489. [CrossRef]

41. Mori, I.C.; Ikeda, Y.; Matsuura, T.; Hirayama, T.; Mikami, K. Phytohormones in red seaweeds: A technical review of methods for analysis and a consideration of genomic data. Bot. Mar. 2017, 60, 153-170. [CrossRef]

42. Briceño-Domínguez, D.; Hernández-Carmona, G.; Moyo, M.; Stirk, W.; van Staden, J. Plant growth promoting activity of seaweed liquid extracts produced from Macrocystis pyrifera under different $\mathrm{pH}$ and temperature conditions. J. Appl. Phycol. 2014, 26, 2203-2210. [CrossRef]

43. Castellanos-Barriga, L.G.; Santacruz-Ruvalcaba, F.; Hernández-Carmona, G.; Ramírez-Briones, E.; Hernández-Herrera, R.M. Effect of seaweed liquid extracts from Ulva lactuca on seedling growth of mung bean (Vigna radiata). J. Appl. Phycol. 2017, 29, 2479-2488. [CrossRef]

44. Hernández-Herrera, R.M.; Santacruz-Ruvalcaba, F.; Zañudo-Hernández, J.; Hernández-Carmona, G. Activity of seaweed extracts and polysaccharide-Enriched extracts from Ulva lactuca and Padina gymnospora as growth promoters of tomato and mung bean plants. J. Appl. Phycol. 2016, 28, 2549-2560. [CrossRef]

45. Silva, L.D.; Bahcevandziev, K.; Pereira, L. Production of bio-Fertilizer from Ascophyllum nodosum and Sargassum muticum (Phaeophyceae). J. Oceanol. Limnol. 2019, 37, 918-927. [CrossRef]

46. Jannin, L.; Arkoun, M.; Etienne, P.; Laîné, P.; Goux, D.; Garnica, M.; Fuentes, M.; Francisco, S.S.; Baigorri, R.; Cruz, F.; et al. Brassica napus Growth is Promoted by Ascophyllum nodosum (L.) Le Jol. Seaweed Extract: Microarray Analysis and Physiological Characterization of N, C, and S Metabolisms. J. Plant Growth Regul. 2012, 32, 31-52. [CrossRef]

47. Stirk, W.; Novak, O.; Strnad, M.; Van Staden, J. Cytokinins in macroalgae. Plant Growth Regul. 2003, 41, 13-24. [CrossRef]

48. Dumale, J.; Gamoso, G.; Manangkil, J.; Divina, C. Detection and Quantification of Auxin and Gibberellic Acid in Caulerpa racemosa. IJAT 2018, 14, 653-660. 
49. El Shoubaky, G.A.; Salem, E.A. Effect of abiotic stress on endogenous phytohormones profile in some seaweeds. IJPPR 2016, 8, 124-134.

50. Hedden, P.; Sponsel, V. A century of gibberellin research. J. Plant Growth Regul. 2015, 34, 740-760. [CrossRef] 